\title{
ANALISIS KADAR SEDIAN PARASETAMOL SYRUP PADA ANAK TERHADAP LAMA PENYIMPANAN DAN SUHU PENYIMPANAN
}

\author{
Vivi Rosalina \\ e-mail: vv.maritha@gmail.com \\ Stikes Bhakti Husada Mulia Madiun; Jalan Taman Praja No 25 Madiun,telp/fax (0351) 491947 \\ Prodi DIII Farmasi,Stikes Bhakti husada Madiun Indonesia
}

\begin{abstract}
Abstrak
Parasetamol merupakan derifat asetanilida yang digunakan sebagai analgetik antipiretik..Parasetamol dianggap sebagai zat antinyeri yang paling aman. Umumnya obat dalam bentuk cair lebih disukai karena mudahnya menelan cairan dan keluwesan dalam pemberian dosis, pemberian lebih mudah untuk memberikan dosis yang relatif sangat besar, aman dan juga mudah diatur penyesuaian dosis untuk anak. Penelitian dilaksanakan di Stikes Bhakti Husada Madiun menggunakan bahan dan alat Paracetamol sirup, Etanol 96\%, Standar Paracetamol, Kertas Saring Whatmann, Spektrofotometer UVVIS, Kuvet Kuarsa, peralatan Gelas disiapkan kemudian dilakuakn uji penetapan kadar paracetamol sirup bersarkan lama penyimpanan dan suhu penyimpanan. Hasil uji stabilitas parasetamol dalam sirup selama 4 minggu dengan perlakuan tertentu pada sampel yaitu penyimpanan dalam suhu lemari es dan suhu ruangan. Kandungan parasetamol didapatkan setiap minggu dengan mengguanakan spektrofotometri. Kandungan parasetamol dalam sirup pada penyimpanan suhu ruangan, untuk minggu ke- $0=370,26 \mathrm{mg}$, minggu ke-1 = 360,73mg, minggu ke- $2=350,43 \mathrm{mg}$, minggu ke-3 = 340,46 mg, minggu ke-4 = 36,55mg. Adapun kandungan parasetamol dalam sirup pada penyimpanan suhu lemari es, untuk minggu ke- $0=$ $360,69 \mathrm{mg}$, minggu ke-1 =220,92 mg, minggu ke-2 =220,92 mg, minggu ke-3 = 210,99 mg, minggu ke-4 $=200,86 \mathrm{mg}$. Sediaan sirup parasetamol pada suhu ruangan dalam jangka waktu penyimpanan 4 minggu relatif stabil dengan memenuhi persyaratan Farmakope Indonesia IV. Adapun penyimpanan dalam suhu lemari es relatif tidak stabil karena dalam jangka waktu 1 minggu sudah mengalami penurunan kadar yang melebihi ketentuan dari Farmakope Indonesia edisi IV. Berdasarkan hasil dalam penelitian disimupulkan bahwa kadar parasetamol sirup terhadap lama penyimpanan dan suhu penyimpanan adalah dalam waktu 4 minggu stabil pada suhu suhu ruangan dan kadar parasetamol berkurang pada pada penyimpanan lemari es
\end{abstract}

Kata kunci: Paracetamol Syrup, Lama Penyimpanan, Suhu Penyimpanan.

\section{Pendahuluan}

Parasetamol merupakan derifat asetanilida yang digunakan sebagai analgetik antipiretik. Parasetamol sebagai obat golongan analgetik-antipiretik yang pada saat ini banyak digunakan oleh masyarakat. Parasetamol dianggap sebagai zat antinyeri yangpaling aman. Umumnya obat dalam bentuk cair lebih disukai daripada bentuk padat karena mudahnya menelan cairan dan keluwesan dalam pemberian dosis, pemberian lebih mudah untuk memberikan dosis yang relatif sangat besar, aman dan juga mudah diatur penyesuaian dosis untuk anak ${ }^{[1]}$.

Sirup parasetamol sering digunakan sebagai antipiretik buat anak-anak, bahkan sebagian orang menyediakannya sebagai stok dirumah untuk menjaga jika anak mereka demam. Penggunaan sirup parasetamol hanya mengobati gejala, sehingga tidak diminum hingga habis. Hal ini menyebabkan obat masih tersisa banyak dan konsumen cenderung untuk menyimpan sisa dari obat tersebut. Sebagian tetap menyimpan disuhu kamar sebagian lagi menyimpan didalam lemari pendingin

Keberhasilan pengobatan tergantung pada kadar zat aktif yang dapat mencapai tempat aksi. Kadar yang kurang dari dosis efektif akan mempersulit penyembuhan penyakit. Hal ini bisa terjadi karena pemberian dosis yang kurang atau karena terjadinya penurunan kualitas obat selama penyimpanan. Dengan demikian kontrol kualitas dan penetapan waktu kadaluwarsa obat sangat diperlukan ${ }^{[1]}$.

Jalur utama degradasi yang menyebabkan parasetamol tidak stabil adalah peristiwa hidrolisis yang memecah parasetamol menjadi p-aminofenol dan asam asetat, dan hal ini dapat terjadi selama 
penyimpanan obat, sehingga kontrol kualitas dan penetapan waktu kadaluwarsa obat sangat diperlukan, selain itu penting untuk memformulasikan obat sedekat mungkin dengan $\mathrm{pH}$ optimumnya untuk memperoleh sediaan yang lebih stabil selama penyimpanan. Tujuan dari penelitian untuk menganalisis kadar sediaan parasetamol sirup pada anak terhadap lama penyimpanan dan suhu penyimpanan.

\section{Metode Penelitian}

Bahan yang digunakan dalam penelitian ini adalah sampel Paracetamol sirup, Etanol 96\%, Standar Paracetamol, Kertas Saring Whatmann. Alat yang digunakan pada penelitian ini adalah Spektrofotometer UV-VIS, Kuvet Kuarsa, Peralatan Gelas, Neraca Analitik.

Prosedur kerja yang pertama adalah Pembuatan Larutan Induk Paracetamol. Dibuat larutan standar induk paracetamol $400 \mathrm{ppm}$ dari serbuk standar paracetamol ditimbang sebanyak $20 \mathrm{mg}$ dan dilarutkan dengan etanol dalam gelas beker. Larutan dimasukkan dalam labu ukur $50 \mathrm{~mL}$ dan kemudian di tera dengan etanol sampai tanda batas.

Prosedur kerja yang kedua adalah penetapan Panjang gelombang maksimum dimana larutan standar paracetamol dengan konsentrasi 6 ppm, Larutan tersebut diukur panjang gelombang maksimumnya pada rentang panjang gelombang antara $200-400$ nm.

Prosedur kerja yang ketiga adalah penetapan Operating time dimana larutan induk paracetamol $400 \mathrm{ppm}$ dipipet sebanyak $0,375 \mathrm{~mL}$ untuk membuat larutan baku dengan konsentrasi 6 ppm sebanyak 25 ml. Larutan baku dengan konsentrasi 6 ppm tersebut dikocok hingga homogen. Ukur absorbansi larutan pada panjang gelombang maksimum sampai diperoleh absorbansi yang relatif konstan dengan rentang pembacaan setiap 2 menit sekali selama 20 menit.

Prosedur kerja yang keempat adalah pembuatan kurva baku dari larutan induk $400 \mathrm{ppm}$ dibuat larutan baku dengan seri konsentrasi $2 ; 4 ; 6$; 8 dan 10 ppm sebanyak $25 \mathrm{~mL}$. Larutan seri yang telah dibuat kemudian diukur serapan masing - masing konsentrasinya pada panjang gelombang maksimum yang diperoleh sebanyak 2 kali pembacaan. Data hasil sorbansi yang diperoleh, selanjutnya dihitung persamaan kurva bakunya sehingga diperoleh persamaan garis $y=a+b x$.

Prosedur kerja yang kelima adalah penentuan ketelitian dari larutan induk parasetamol $400 \mathrm{ppm}$ dibuat larutan baku dengan konsentrasi 8 ppm sebanyak $25 \mathrm{~mL}$. Larutan tersebut diukur serapannya pada panjang gelombang maksimum. Uji ketelitian ini dilakukan dengan 10 kali pengulangan.

Prosedur kerja yang keenam adalah Penetapan kadar sampel dimana sampel paracetamol sirup di ukur $20 \mathrm{ml}$ dan dilarutkan dengan etanol. Larutan disaring dengan kertas saring Whatman no. 42 dan dimasukkan dalam labu takar $50 \mathrm{~mL}$ kemudian ditera dengan etanol sampai tanda batasd. Larutan tersebut dipipet sebanyak $0,25 \mathrm{~mL}$, kemudian diencerkan dengan etanol hingga konsentrasi 4 ppm sebanyak $25 \mathrm{~mL}$. Ukur serapan larutan pada panjang gelombang maksimum. Apabila serapan dari larutan sampel uji masih berada di luar range serapan larutan standar, maka larutan diencerkan hingga serapannya masuk di dalam range. Penetapan kadar dilakukan dengan pengulangan sebanyak 10 kali.

Prosedur kerja yang ketujuh adalah Penentuan ketepatan (akurasi) dimana larutan sampel uji dipipet sebanyak $0,25 \mathrm{~mL}$ dan dimasukkan ke dalam labu ukur $25 \mathrm{~mL}$ kemudian ditambahkan $1 \mathrm{~mL}$ larutan baku parasetamol dengan konsentrasi 400 ppm. Tepatkan volume larutan sampai tanda batas dengan etanol dan dikocok hingga homogen. Larutan tersebut diukur serapannya pada panjang gelombang maksimum.Uji ketepatan metode dilakukan dengan pengulangan sebanyak 10 kali. Hasil absorbansi digunakan untuk menghitung harga perolehan kembali (\%recovery).

Penentuan seletivitas (spesifitas) dimana standar dan larutan contoh uji diukur spektra UV masing-masing larutan pada panjang gelombang 200-400 $\mathrm{nm}$. Bandingkan hasil kedua spektra UV tersebut.

Ketangguhan metode dimana larutan sampel uji diukur serapannya pada panjang 
gelombang maksimum, panjang gelombang maksimum +1 dan panjang gelombang maksimum -1.Uji ketangguhan metode dilakukan dengan pengulangan sebanyak 10 kali.

\section{Hasil dan pembahasan}

Pada stabilitas parasetamol dalam sirup selama 4 minggu dengan perlakuan tertentu pada sampel yaitu penyimpanan dalam suhu lemari es dan suhu ruangan.

Tabel 1. Kandungan parasetamol dalam sirup paracetamol

No Waktu Kadar dalam suhu ruang

(mg) Kadar dalam suhu lemari es(mg)

$1 \quad$ Minggu $0 \quad 370,26$ 360,69

$2 \quad$ Minggu $1 \quad 360,73$

220,92

$3 \quad$ Minggu $2 \quad 350,43$

220,92

$4 \quad$ Minggu $3 \quad 340,46$

210,99

$5 \quad$ Minggu $4 \quad 360,55$

200,86

Larutan baku paracetamol dengan konsentrasi tertentu di buat dengan cara melarutkan bahan paracetamol ke dalam pelarut yang digunakan. Pelarut yang digunakan dalam penelitian ini adalah metanol. Penggunaan metanol sebagai pelarut karena paracetamol larut dalam metanol. Selain itu juga, diketahui metanol memiliki serapan panjang gelombang di bawah $210 \mathrm{~nm}$. Sehingga metanol akan meneruskan atau tidak akan menyerap sinar dengan panjang gelombang diatas $210 \mathrm{~nm}$. Akibatnya metanol tidak akan menganggu spektrum serapan dari paracetamol.

Panjang gelombang maksimum $(\lambda$ maks) merupakan panjang gelombang dimana terjadi eksitasi elektronik yang memberikan absorbansi maksimum. Alasan dilakukan pengukuran pada panjang gelombag maksimum adalah perubahan absorban untuk setiap satuan konsentrasi adalah paling besar pada panjang gelombang maksimum, sehingga akan diperoleh kepekaan analisis yang maksimum. Penentuan panjang gelombang pada penelitian ini dilakukan dengan mengukur absorbansi dari parasetamol pada panjang gelombang ultraviolet yaitu antara panjang gelombang $200 \mathrm{~nm}-400 \mathrm{~nm}$. Dari hasil penelitian yang diperoleh panjang gelombang maksimum adalah $248 \mathrm{~nm}$. Secara teoritis serapan maksimum untuk parasetamol adalah $244 \mathrm{~nm}$, terjadi pergeseran karena pada parasetamol memiliki gugus auksokrom yang terikat pada gugus kromofor.

Linieritas menunjukkan kemampuan suatu metode analisis untuk memperoleh hasil pengujian yang sesuai dengan konsentrasi analit dalam sampel pada kisaran konsentrasi tertentu ${ }^{[2]}$. Hal ini dapat dilakukan dengan cara membuat kurva kalibrasi dari beberapa set larutan standar yang telah diketahui konsentrasinya. Kurva kalibrasi merupakan metode standar yang dapat digunakan untuk menentukan konsentrasi suatu analit berdasarkan hukum Lambert-Beer. Pengukuran absorbansi larutan standar parasetamol pada panjang gelombang maksimum dikarenakan pada daerah tersebut akan diperoleh titik serapan terbesar untuk setiap larutan standar parasetamolnya.

Hasil pengukuran menunjukkan bahwa semakin besar konsentrasi larutan standar parasetamol yang diukur maka semakin besar pula absorbansi yang diperoleh. Hal ini dikarenakan pada konsentrasi yang semakin tinggi,tingkat kepekatan senyawa parasetamol juga semakin tinggi.Selain itu, hukum Lambert-Beer menunjukkan bahwa perubahan konsentrasi suatu sampel tertentu akan mengubah absorbansi pada tiap panjang gelombang dengan suatu faktor yang konstan. Pembuatan kurva kalibrasi standar dilakukan dengan memplot larutan standar parasetamol (sumbu $\mathrm{x}$ ) dan absorbansi (sumbu y), kemudian titik tersebut dihubungkan dengan garis lurus.

Ketelitian atau presisi adalah ukuran yang menunjukkan derajat kesesuaian antara hasil uji individual, diukur melalui penyebaran hasil individual dari rata-rata jika prosedur diterapkan secara berulang pada sampel-sampel yang diambil dari campuran yang homogen. Keseksamaan dapat dinyatakan sebagai repeatability (keterulangan) atau reproducibility (ketertiruan). Repeatability adalah 
keseksamaan metode jika dilakukan berulang kali oleh analis yang sama ada kondisi sama dan dalam interval waktu yang singkat.Reproducibility adalah keseksamaan metode jika dikerjakan pada kondisi yang berbeda. Nilai presisi dihitung menggunakan standar deviasi (SD) untuk menghasilkan Relative Standard Deviasion (RSD) atau Coeficient Variation (CV). Kriteria seksama diberikan jika metode memberikan nilai $\%$ RSD $\leq 2 \%$. Semakin kecil nilai standar deviasi yang diperoleh, maka makin kecil pula nilai koefisien variasinya ${ }^{[3]}$.

Akurasi dari suatu metode analisis adalah kedekatan nilai hasil uji yang diperoleh dengan prosedur tersebut dari nilai yang sebenarnya. Akurasi merupakan ukuran ketepatan prosedur analisis [4]. Kecermatan dinyatakan sebagai persen perolehan kembali (\%Recovery) analit yang ditambahkan.

Ketangguhan metode adalah derajat ketertiruan hasil uji yang diperoleh dari analisis sampel yang sama dalam berbagai ondisi uji normal, seperti laboratorium, analisis, instrumen, bahan pereaksi, suhu, hari yang berbeda, dan lain-lain. Ketangguhan biasanya dinyatakan sebagai tidak adanya pengaruh perbedaan operasi atau lingkungan kerja pada hasil uji [4]. Penentuan ketangguhan metode dilakukan dengan mengukur serapan larutan sampel pada panjang gelombang maksimum, panjang gelombang maksimum +1 . range nilai persen $(\%)$ recovery analit yang dapat diterima adalah $90-110 \%$. Range tersebut bersifat fleksibel tergantung dari kondisi analit yang diperiksa berdasarkan jumlah sampel dan kondisi laboratorium. Nilai \%recovery yang diperoleh masuk dalam range yang dapat diterima yaitu $90-110 \%$, sehingga dapat dikatakan metode ini memiliki akurasi yang baik.

Uji selektivitas bertujuan untuk mengetahui perubahan bentuk kurva maupun pergeseran panjang gelombang parasetamol tersebut terhadap akibat penambahan senyawa yang ada dalam sampel obat sediaan sirup tersebut. Hasil pengukuran spektra UV standar dan sampel uji yang diperoleh dari penentuan selektivitas ini menunjukkan spektra UV untuk standar parasetamol memiliki panjang gelombang $247 \mathrm{~nm}$ dengan peak sebesar 0,510 serta spektra UV untuk sampel memiliki panjang gelombang $248 \mathrm{~nm}$ dengan besar peak 0,258 dan panjang gelombang $362 \mathrm{~nm}$ dengan besar peak 0,036 . Adanya dua puncak spektra UV yang berbeda dalam sampel tersebut dikarenakan dalam sampel uji mengandung lebih dari satu jenis zat aktif obat. Berdasarkan hasil perbandingan kedua spektra UV menunjukkan edekatan hasil antara spektra UV sampel yaitu pada panjang gelombang $248 \mathrm{~nm}$ dengan spektra UV standar pada panjang gelombang $247 \mathrm{~nm}$. Hal ini menunjukkan bahwa dalam sampel mengandung parasetamol sehingga metode analisis memiliki selektivitas yang baik dalam pengukuran Hasil yang diperoleh juga menunjukkan terjadinya pergeseran panjang gelombang parasetamol dari 247 $\mathrm{nm}$ ke arah panjang gelombang yang lebih besar yaitu $248 \mathrm{~nm}$ (pergeseran batokromik) yang disertai dengan penurunan intensitas serapan yang disebut dengan efek hipokromik.

Penentuan kadar parasetamol dilakukan dengan cara mengukur larutan sampel uji yang diduga mengandung parasetamol pada panjang gelombang maksimum yaitu 247 $\mathrm{nm}$ dengan pengulangan sebanyak 10 kali. Penetapan kadar ini bertujuan untuk menjamin mutu serta keamanan suatu produk obat. Pada penetapan kadar parasetamol ini digunakan Limit of Detection (LOD) atau batas deteksi untuk melihat kosentrasi terendah yang masih dapat terdeteksi oleh suatu alat.

Data menunjukkan bahwa nilai perolehan kadar rata-rata parasetamol dalam sampel obat sediaan tablet dengan merk dagang yaitu sebesar $360,686 \mathrm{mg}^{[5]}$. bahwa besarnya kadar parasetamol dalam sediaan yaitu 500. Hasil rata-rata kadar parasetamol yang diperoleh yaitu kurang dari besarnya kadar yag seharusnya ada dalam obat sediaan tablet tersebut. Menurut persyaratan Farmakope Indonesia (FI) Edisi IV tahun 1995, bahwa besarnya kadar zat aktif senyawa obat dalam sebuah obat yaitu tidak kurang dari $90 \%$ dan tidak lebih dari $110 \%$. Hasil yang diperoleh dari pengujian ini menunjukkan ketidaksesuaian antara hasil 
pengujian dengan standar yang telah ditetapkan. Faktor yang mempengaruhi ketidaksesuain hasil pengujian yaitu terdapat pada pelarut yang digunakan dalam pengujian yaitu etanol 96\%. Etanol termasuk dalam pelarut organik yang mudah menguap sehingga sebelum pengukuran sampel dengan alat spketrofotometer dimungkinkan sebagian zat aktif parasetamol dalam larutan sampel telah menguap bersama dengan pelarut etanol tersebut yang menyebabkan hasil penyerapannya berkurang serta kurangnya faktor penggocokkan sebelum larutan sampel hendak diukur juga mempengaruhi hasil yang didapatkan dalam pengujian, sebab larutan harus benar-benar homogen agar didapatkan hasil yg maksimal dalam pengujian.

Telah dilakukan uji stabilitas parasetamol dalam sirup selama 4 minggu dengan perlakuan tertentu pada sampel yaitu penyimpanan dalam suhu lemari es dan suhu ruangan. Kandungan parasetamol didapatkan setiap minggu dengan mengguanakan spektrofotometri. Kandungan parasetamol dalam sirup pada penyimpanan suhu ruangan, untuk minggu ke- $0=370,26 \mathrm{mg}$, minggu ke-1 = $360,73 \mathrm{mg}$, minggu ke- $2=350,43 \mathrm{mg}$, minggu ke- $3=340,46 \mathrm{mg}$, minggu ke- $4=$ $36,55 \mathrm{mg}$. Adapun kandungan parasetamol dalam sirup pada penyimpanan suhu lemari es, untuk minggu ke- $0=360,69 \mathrm{mg}$, minggu ke-1 $=220,92 \mathrm{mg}$, minggu ke-2 $=220,92 \mathrm{mg}$, minggu ke-3 = 210,99 mg, minggu ke-4 $=200,86 \mathrm{mg}$. Sediaan sirup parasetamol pada suhu ruangan dalam jangka waktu penyimpanan 4 minggu relatif stabil dengan memenuhi persyaratan Farmakope Indonesia IV. Adapun penyimpanan dalam suhu lemari es relatif tidak stabil karena dalam jangka waktu 1 minggu sudah mengalami penurunan kadar yang melebihi ketentuan dari Farmakope Indonesia edisi IV. Sehingga disarankan Sediaan sirup Parasetamol lebih baik disimpan pada suhu kamar.

\section{Daftar Pustaka}

[1] Arisandi, W, S., 2008. Pengaruh pH Terhadap Stabilitas Sirup Paracetamol, (online) http://www.scribd.com.diakses 23 Mei 2016).

[2] Ermer, J., dan Miller, J.H.McB, 2005, Method Validation in Pharmaceutical Analysis, A Giude to Best Practice, Weinheim: Wiley-VchVerlag $\mathrm{GmbH}$ dan Co. KGaA. Halaman 253

[3] Riyadi, W, 2009, Validasi Metode Analisis, tersedia di http://www.chemis-

try.org/artikel_kimia/kimia_analisis/val idasi-metode-analisis/, diakses pada tanggal 4 mei 2016

[4] Rohman, A .,Gandjar, G.H., 2007.Kimia Farmasi Analisis. Yogyakarta: Pustaka Pelajar.

[5] Werner, D., Thuman, C., Maxwell, J., 2010, Apa yang Anda Kerjakan Bila Tidak Ada Dokter (Where There Is No Doctor).Yogyakarta 